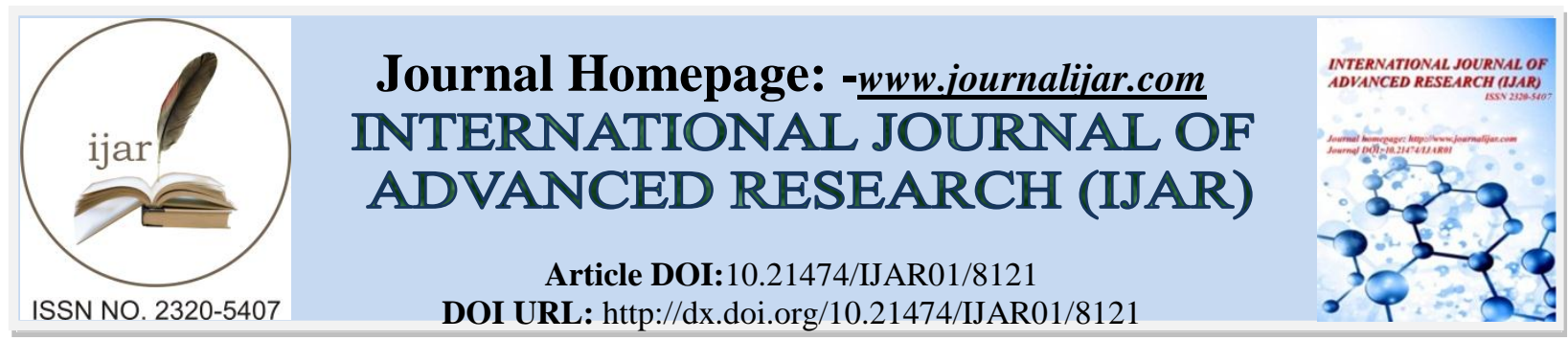

RESEARCH ARTICLE

\title{
MEASURING EMPLOYEES' PERCEPTION OF THE EXISTENCE OF ORGANIZATIONAL POLITICS AND JOB SATISFACTION OF DIVINE WORD COLLEGES' EMPLOYEES IN ILOCOS REGION, PHILIPPINES.
}

\author{
Damianus Abun, Theogenia Magallanes, Sylvia Lalaine Grace Foronda, Emma P. Paynaen, Fredrick Agoot \\ and Merylin Pre.
}

\section{Manuscript Info}

Manuscript History

Received: 01 October 2018

Final Accepted: 03 November 2018

Published: December 2018

Keywords:-

organizational politics, blaming others, impression management, ingratiation, job satisfaction..

\begin{abstract}
The study wanted to determine the relationship between organizational politics and job satisfaction of employees of Divine Word Colleges in Ilocos Region. The study used descriptive research design and aided by fact finding inquiry. The population of the study are the employees of the Divine Word Colleges in Ilocos region, Philippines and since the number of employees were limited, therefore, total enumeration method of sampling was used. Questionnaires were utilized to gather the data and weighted mean was used to determine the level of perception of employees of the existence of organizational politics and job satisfaction. Pearson $r$ was used to determine the relationship between the two variables, between organizational politics and job satisfaction. The finding revealed that employees somewhat agree to the existence of organizational politics of Divine Word Colleges in Ilocos region but as a whole, there is no correlation between organizational politics and job satisfaction of employees. However, taking it singly, there is a correlation between organizational politics in terms of blaming others and job satisfaction.
\end{abstract}

Copy Right, IJAR, 2018,. All rights reserved.

\section{Introduction:-}

Politics is one of natural human tendencies, which is often called, "homo politico" or political man and this is the reason why Aristotle (384-322) called human being as political animal. He/she is called political animal because he/she has the tendency to control or influence the others in society or organization. Aristotle portrayed the idea of politics as a master-craft and thus it is tolerable and practical social phenomenon. It is a social phenomenon because it is imbedded in the social nature of human beings, but it is allowed only to the point of tolerability. By interacting with another or more persons produce a relationship which is called political (Omisore, Nweke, 2014). Within such relationship one tries to influence and control the others and the only reason why someone would get involved in politics is to satisfy their thirst for power. In other words, organizations are not inherently apolitical (Bacharach \& Lawler 1980). Aristotle wrote that politics stems from a diversity of interests, and it is constructive only if it is within tolerable level and therefore those competing interests must be resolved in some way (Vigoda-Gadot \&Drory, 2006). People engage in politics because they view politics as a way of getting what they want at the expense of others in order to get ahead of others. They benefit from such behavior or else there is no reason to engage in political behavior (Meriac\& Villanova, cited by Vigoda-Gadot \&Drory, 2006).

Corresponding Author:-DamianusAbun. 
Given the fact that it is a social phenomenon, and therefore, one cannot dismiss the negative effect of organizational politics. Too much politicking can have an unintended consequence on the organization. Gandz and Murray (1980) and Hochwarter, et.al (2003) have recognized such consequences. They argued that political environment at work may affect the employees in different ways ranging from extremely beneficial to enormously harmful. They contend that the importance of Organizationl Politics lies in its potential consequences and effects on work outcomes. It can either be good or bad at the end. Recognizing its negative effect on the work outcomes and job satisfaction, the current study would like to investigate the extent of employees' perception of organizational politics in Divine Word Colleges and the extent of its consequence on job satisfaction of employees.

\section{Theoretical Frameworks:-}

\section{Understanding Organizational Politics and Political Behaviors:-}

Politic is a social phenomenon and is a part of organizational life and cannot be avoided. Each member of the organization has his/her own interest and different individual has differing interest. There can be a lot of conflicting of interest. Consequently, each member exerts any efforts to get what he/she wants. Naturally, competitions among members cannot be avoided. To get ahead of others and in order to get access to the limited resources, possibility of back-room dealing, manipulation, or hidden agenda for personal gain may happen (Gandz\& Murray, 1980). Within such context, organizational politics is seen as a behavior of people in organization or institution which aims to further one's interest or the interest of a group over the interest of other people or another group (Pam, 2013). These behaviors are not sanctioned by the organization, but they are individual's own initiatives. These are actions by individuals which are directed toward attainment of their own self-interests without regard for the interest of others or other group within the organization. Often time the motivation behind the political behaviors is hidden from the target action and it happens when there is competition over limited resources ((Kacmar and Baron 1999). It is along such argument, Mintzberg (1983) contended that organizational politic is "individual or group behavior that is informal, ostensibly parochial, typically divisive, and above all in a technical sense, illegitimate - sanctioned neither by formal authority, accepted ideology, nor certified expertise." It has been recognized as the process of leveraging an informal network to accomplish a task or goal. The outcome of such informal network can be negative when solely used to promote self-interest and are often detrimental to the organization - promoting the agenda of individuals (Fullerton, 2017). It is recognized as an individual strategy to accomplish the individual motives and upholding individual interest over the organizational interest, without regard to the impact on the organization as a whole (Virtual Learning Environment, 2018). It is an informal, unofficial, and sometimes behindthe-scenes efforts to sell ideas, influence an organization, increase power, or achieve other targeted objectives (Brandon \&Seldman, 2004).

Political behavior is known to be an illegitimate exercise of influence or power over other members of the organization to achieve selfish interest. To get what they want; the political actors use different strategies in order to influence others to support them, to get what they want but to the disadvantages of other group of the organization members. It is another way of pursuing individual agenda and self-interest in an organization without regard to their effect on the organization's efforts to achieve its goals (Alen, et.al, 1979). Influences by individuals may serve personal interests without regard to their effect on the organization itself (WebFinace, 2012). Some of the personal advantages may include access to tangible assets, or intangible benefits such as status or pseudo-authority that influences the behavior of others.

Organizational politics and political behavior is not separated because when we talk about organizational politics, we refer to political behavior of individual person or groups within the organization. This is a natural tendency of human beings to be involved in politicking wherever they are (Vredenburgh\& Shea-VanFossen, 2010). This natural tendency can be seen in the workplace when the workplace environment is marked by ambiguity, uncertainty and bureaucratic. These ambiguity and uncertainty are caused by political behavior of organization members. Froman (1962) contended that political behavior in organization are those activities that are not required by employees' job description but that influence or attempt to influence the distribution of advantages and disadvantages within the organization.

Often time, political behavior in organization does not limit only to the organization members within the organization but it can also be extended beyond the borders when the situation allows. Politics inside the organization often spills over the fence to include outsiders into organization's politics. Therefore, Farrel and Pettersen (1982), classified three patterns of political behavior and these are internal- external dimensions, the vertical-lateral dimension and the legitimate -illegitimate dimension. The internal-external dimension of political 
behavior attempts to involve not only with the individuals within the organization but to involve the outsiders into organizational matters. Take an example leaking the information to the outsiders, forming alliances with the outsiders, whistleblowing, etc. Example of internal political behaviors are on the other hand, involving the individuals with the organization such as asking for favors, trading agreements, symbolic protest gestures, forming alliances with other member of the organization. According to Farrel and Pettersen, it is possible that organizational members may progress from internal to external activities when they see the possibility to involve the outsiders. This may happen when an individual employee cannot change the situation without the participation of the outsiders. In terms of vertical-lateral dimensions of political behavior involves political activities related to supervisors and subordinates such as complaining to supervisors, by passing the chain of command, crisscrossing communication channels, etc. Finally, the legitimate and illegitimate dimension of political behavior involves political activities that are violating the rule of the game. This includes behaviors that are not accepted by the norms of the organization.

Nowadays political behavior has been gaining its ground in the organization because people find it as a good alternative of getting what they want. It is often seen as a more successful means to get what one wants than through job-related behaviors. Let us take an example of promotion. Promotion is often time not based on job performance but because of a good relationship with the superiors. This is confirmed by the studies that political behavior is found to affect not only promotions, but also personnel decisions and actions such as performance appraisals (e.g ., Ferris \& Judge, 1991; Longenecker, 1989; Luthans, Hodgetts, \&Rosenkrantz, 1988). This is also reported in the study of Luthans et al. that the managers who earned promotions quickly spent more time engaging in politicking in social networks.

\section{Other Causes of organizational Politics:-}

There are several different causes of organizational politics. It can be caused by individual personality, scarcity of resources and role ambiguity. It cannot be denied that each member of the organization has different personalities. Because of such differences, some came in to the organization with different styles in relating to other member of the organization. For example, some can relate well to others, while others cannot and others who are self-conscious can monitor themselves and alter their reactions depending upon the situation they are in, and inspire confidence and trust (Ferris et al., 2000). According to research, these kinds of people have political skills and have high internal locus of control. It was found that those who have high political skills can perform well in their job and they are efficient in delivering the results and can get a favorable performance rating from their management (Ferris, Fedor, \& King, 1994; Kilduff \& Day, 1994). Further study pointed out that these people believe in themselves that they perform their job better than others. These people expect to engage in more political behavior and perceive politics around them to a greater degree (Valle \&Perrewe, 2000). Goltz (2014) in his study, concluded that these political behaviors are reinforced when the results bring desired changes.

Organizational politics is also caused by scarcity of resources. It is a fact that not all organizations have the means to provide everything the employees want. There are scarcities of resources. It is a fact that when there is a scarcity of resources, there is tendency to behave politically to get access to the limited resources. Any type of scarcity such as financial scarcities, talent scarcities can cause political relationships (Dubrin, 2001). Besides scarcity of resources, political behavior is reinforced by task ambiguity in which employees do not have clear role and responsibility. Role ambiguity allows individuals to describe and redefine their roles that can create conflict with the job of other people. Role ambiguity causes uncertainty. According toDubrin (2001), when there is uncertainty, people tend to behave politically. They rely on politic to achieve what they want to achieve. This is further confirmed by the study of Muhammad (2007) that when people do not understand well their job responsibilities, they perceive the organization as more political. He explained that ambiguous environment tends to create political behavior as Goltz (2014), argued earlier that political behavior tends to occur in competitive environments in which there are unclear rules for the distribution of outcomes and resources and why the true motivations behind political activities tend to be hidden. Political situation tends to be strengthened by the type of organizational structure. It often happens within hierarchical organizational structure in which power is concentrated on the top layer. Within such structure, those who are at the lower level have less power and no power at all for those at the bottom. The situation provides a chance for people to look for power (Dubrin, 2001). Such environment makes it hard for democratic decisionmaking process to be applied. When people do not feel part of the decision-making process, they create their own way to express their opinion. 


\section{Types of organizational politics:-}

Sussman, et.al (2002) have identified different types political behaviors in organization and these are attacking or blaming others, holding information, impression management, developing base of support, ingratiation, forming coalition or alliances, and creating obligation. However, for the sake of the current study, the study focuses only three of the political behaviors in the organization and these are blaming others, impression management, and ingratiation. These three political behaviors are commonly observed in the context of Divine Word Colleges in Region I, Philippines.

\section{Blaming Others:-}

The tendency of every person is to look good in the eyes of other people and such tendency affects the way how they behave and react to the problem or situation that affects them. They are so careful in dealing with problems because they tend to protect their good image and therefore they do not accept mistakes or wrong doing but throw the blame to other people. We may not consider blaming as a strategy because it is unconscious reaction when one does not get the result that he/she wants but it is just a natural tendency that comes out naturally when our self-image is under attack. The reason why we are blaming others is because we are more interested in being right than changing our behavior, taking responsibility and getting the results that we want. When things go wrong, instead of taking the blame and responsibility, but one throws the blame to others (Sofi, 2013). However, others argue that blaming is a strategy to maintain good image. It is a strategy that includes reactive and proactive behaviors as pointed out by Allen (1979). Allen contends that reactive behavior happens after the incidence in which the person washed his/her hands of his/her involvement in the incidence or failing situation. While on the other side, proactive behavior happens when a person makes another person or rival looked bad in the eyes of a significant member of the organization.

\section{Impression Management:-}

Impression management has been long in the history. This theory is originated in the theory of Goffman in 1950s and then it was rooted in interactionist sociology theory (Tedeschi \&Melburg, 1984). It is an effort by individuals to create and to protect an image held by others (Bozeman \& Kacmar, 1997). It refers to how a person manages his/her image in front of the eyes of other people. He/she wants to appear as a nice person always. The persons belong to this group tends to build good image of being liked, a nice person (Allen, 1979). It is considered as one the strategies of organizational politics and according to Drory and Vigoda Gadot (2010), this kind of political behavior is influenced by the culture. Culture has allowed such kind of behavior to be acceptable because it is beneficial for career advancement and because merit alone does not guarantee for promotion (Drory\&Zaidman, 2006). In addition, persons who engage in the impression management often time preserve their self-esteem, and very cooperative and can access to the limited resources by ingratiation to the management. Culture has accepted that engaging in this kind of political behavior is beneficial for getting reward and avoiding punishment when they committed something wrong. People are used to please the supervisor, colleagues, themselves and to their job. They ingratiate their boss through praise and try to be nice and cooperative all the time. They also tend to work hard and often time beyond their office hours and show their boss that they are committed. Lastly, they are also trying to show other employees that they are more competent on their job (Wayne \& Ferris (1990).

\section{Ingratiation:-}

Employees as human being will always have their way to get what they want. If they cannot get it through blaming others, impression management but they can get it through ingratiation. It is a political behavior to influence others. It is a simple method of influence that seeks to get others or superiors to like you and hence comply with your requests. According to Jones (1964) ingratiation has three methods, and these are other-enhancement (flattery), opinion-conformity (agreement) and self-presentation. Flattery is often known when a person expresses his/her admiration of their achievement and others. They tend to exaggerate their achievement and downgrade their mistakes. It is the way how they get your attention and respect. Agreement is seen when a person always agrees with the other person even if he/she is not. This person is always impressed by the ideas of others and never challenge. $\mathrm{He} / \mathrm{she}$ smiles even if he/she disagrees with. Lastly, self-presentation is a way how a person presents himself-herself to be like by others. They dress to impress people around them. They speak well and appear to be knowledgeable but not arrogant. According to Allen, et.al, (1979) ingratiation happens when a person praises another to create a good rapport. In their study, they found that lower level employees use more colorful expression like "buttering up the boss". 


\section{Job satisfaction :-}

One of the concerns of management is how to improve and maintain job satisfaction of the employees. It is the level of their contentment toward the job. Their satisfaction toward the job is important because it affects their performance on the job. In other words, when they are satisfied, they can perform well but when they are not satisfied, their performance decreases and consequently the organization fail to achieve its objectives.

One of the most common definitions of job satisfaction is taken from Lock (1976). He defined job satisfaction as a pleasurable or positive emotional state resulting from the appraisal of one's job or job experiences. Based on such definition, there are three components of job satisfaction such as emotional, cognitive and behavioral components. The emotional component refers to job-related feelings such as boredom, anxiety, acknowledgement and excitement. The cognitive component of job satisfaction pertains to beliefs regarding one's job whether it is respectable, mentally demanding / challenging and rewarding. Finally, the behavioral component includes people's actions in relation to their work such as tardiness, working late, faking illness in order to avoid work (Bernstein \& Nash, 2008). The most recent one of the definition of job satisfaction is given by Hulin and Judge (2003). Hulin and Judge define job satisfaction as multidimensional psychological responses to an individual's job and that these personal responses have cognitive (evaluative), affective (or emotional), and behavioral components. Job satisfaction can be understood in terms of its relationships with other key factors, such as general well-being, stress at work, control at work, home-work interface, and working conditions (Tomazevic, Seljak, Aristovnik, 2014).

When an organization staffed with dissatisfied employees, the organization will have trouble in achieving its goals (Breaux, Munyon, Hochwarter, \& Ferris, 2009). According to their study, when the organizational politics perceived to be present, the job satisfactions of employees tend to be lower. There have been a lot of theories along job satisfaction such as Maslow's (1943) Hierarchy of Needs, Hertzberg's (1968) Two-Factor (Motivator-Hygiene) theory and many more others. These theories have linked job satisfaction to productivity, motivation, job performance, and even general life satisfaction. From those theories and research, they pointed to one finding that the emotional state of an individual is affected by interactions with their work environment. Therefore, the management should recognize the importance of job satisfaction because a person's attitude and beliefs may affect his or her behavior positively or negatively. Job satisfaction is multidimensional since its causes are not only from one single factor such pay or salary, but it depends on many factors of the organization such as organizational politics.

\section{Related studies:-}

There have been a lot of studies in line with the current study. Based on the review of related studies, organizational politics may and may not necessarily have a direct bad effect on the job satisfaction and consequently affecting job satisfaction and job performance. It is argued that culture and other aspect of work environment can mediate the effect of organizational politics. Teamwork culture, trust and social support can mediate the effect of organizational politics toward job satisfaction. Elkhalil, (2017) conducted a cross-cultural study on organizational politics and employee behavior: a comparison between the U.S. and Lebanon. The study somehow gives us answer as to the reasons why there is no correlation between organizational politics and job satisfaction. Culture has something to do with how people or employees perceive or react toward organizational politics. Elkhalil (2017) showed that Lebanese employees are more stressed and experience higher job anxiety and turnover intent. Low motivation level is also evident among the Lebanese employees opposed to their U.S. counterparts.

Singh (2012) conducted a study on the relationship between organizational politics, jobs satisfaction and organizational commitment at UiTIM Sarawak, Malaysia. His study found that organizational politics have a negative relationship with job satisfaction and organizational commitment. This was also confirmed by Malik, (2009) when he conducted similar study on the relationship between age, perceptions of organizational politics and job satisfaction. The result of study was still in line with the findings of Singh (2012) that there is no correlation between perception on organizational politics and with different dimensions of job satisfaction. Gull and Zaidi (2012) confirmed the finding of such study that the perception of organizational politics is negatively connected to the job satisfaction level of the employees in the health sector. It strengthened was further by study of Butt, et.al (2013). Their study was on perception of organizational politics and job outcomes in a public-sector organization. The concluded that there is no correlation between organizational politics and job satisfaction and organizational commitment particularly in the environment where the employees' value is more on teamwork comparing to those who value less on teamwork. This study contends that organizational politics do not cause job dissatisfaction and low commitment if other factor such as teamwork is working well. This view is somehow supported by the study of 
Vigoda-Gadot and Talmud. (2010) on the organizational Politics and job outcomes: The Moderating Effect of Trust and Social Support. The study found that trust and social support can reduce or minimize the impact of organizational politics on the job outcome. Such finding strengthens the view that organizational politics may not necessarily bring a negative effect on job satisfaction and job out come if there is trust and social support between employees and management and among employees. Similar to that argument, Vigoda-Gadot (n.d) on the organizational politics and job performance and the moderating effect of social capital pointed out that social support is a good moderator of the relationship between perception on organizational politics and performance. In other words, the potentially negative aftermaths of POPs can be controlled and reduced when trust and social support dominate the intra-organizational climate.

However, it is a fact that not all organizations have a solid teamwork, trust and social support, and therefore organizational politics still affects the job satisfaction. Studies also have pointed out that it can trigger employees to leave the organization and neglect their duties as pointed out by Vigoda-Gadot (2000), on the organizational politics, job attitudes, and work outcomes. Though in general the finding of the study is in consonance with the finding of other studies that perception of organizational politics is not correlated with job attitudes such as job satisfaction and organizational commitment, but it has a positive relationship with intention to leave the organization and a stronger positive relationship with negligent behavior.Delle, (2013) investigated on the influence of perception of organizational politics on employee job involvement and turnover intentions. The result of study indicated that perceptions of organizational politics was positively and significantly related to job involvement, but no significant relationship was found between perception of organizational politics and turnover intentions.

Based on those studies presented, we conclude that organizational politics may and may not really be pointed out as having direct negative impact on job satisfaction and performance. It can have a negative impact on job satisfaction if trust, social capital such team work and supportive cultures are not strong enough to minimize the effect of organizational politics. But these studies have also pointed out that organizational politics have negative impact on job satisfaction and therefore must be minimized to prevent it from causing job dissatisfaction.

\section{Conceptual Framework:-}

Independent VariablesDependent Variable:-

\section{Organizational Politics Perception}

- Blaming Others

- Impression Management

- Ingratiation

Figure 1: The conceptual framework explains the theory of the study that organizational poittcs arrect tne job satisfaction of employees.

\section{Statement of the Problems:-}

The study wanted to determine the relationship between employees' perception of the existence of organizational politics and their job satisfaction, specifically to answer the following questions:

1. What is the employees' perception of the existence of organizational politics in their institution in terms of

a. Blaming others

b. Impression Management

c. Ingratiation

2. What is the job satisfaction of employees?

3. Is there a relationship between employees' perception of organizational politics and job satisfaction? 


\section{Assumption:-}

The study assumes that employees' perception of organizational politics affects the job satisfaction of employees and it can be measured. It is also assumed that the questionnaires are valid, and the methodology of the study is correct and valid.

\section{Hypothesis:-}

Pervious researchers found that organization that is allowing too much political behaviors have a significant relationship with commitment to the organization (Maslyn\&Fedor, 1998; Nye \& Wit, 1993), decrease job satisfaction (Ferris et al., 1996; Hochwarter et al., Kacmar et al., 1999), perform worse on the job (Anderson, 1994), and have higher levels of job anxiety (Ferris et al., 1996; Kacmar\& Ferris, 1989), and have a higher incidence of depressed mood (Byrne et al., 2005). Thus, the study hypothesizes that there is a relationship between organizational politics and job satisfaction of employees and faculty.

\section{Scope and Delimitation of the Study:-}

The study is limited to determine the employees' perception of the existence of organizational politics and job satisfaction of Divine Word Colleges in Ilocos Norte, and Ilocos Sur. The variables under employees' perception of organizational politics are blaming others, impression management and ingratiation.

\section{Research Methodology:-}

This part presents the research design used in this study, data gathering instruments, population, locale of the study, data gathering procedures and statistical treatment of data.

\section{Research Design:-}

Since the study was a quantitative research, thus, the study used descriptive method of research design and factfinding inquiry to assess and explain the level of employees' perception of organizational politics and its effect on the job satisfaction. Descriptive research assesses, determines and reports the way things are. It does not attempt to go beyond the facts. It involves recording and description, analysis and interpretation of things or conditions that now exists. In other words, it describes and explains the data that have been collected on research sample.

The first problem was to determine the level of employees' perception of the existence of organizational politics in terms of blaming others, impressing others and ingratiation. The second part is about the level of job satisfaction of employees.

\section{Locale of the Study:-}

The study was conducted in the Divine Word Colleges in Ilocos region which include Divine Word College of Vigan, and Divine Word College of Laoag. These colleges are in Ilocos Sur, and Ilocos Norte.

\section{Population:-}

The population of the study was taken from all employees working in these colleges. There were 270 employees taken as respondents of the study. Since the population of the study was small, so the total enumeration sampling was used in which all employees of the two colleges were taken as the respondents of the study. Total enumeration was taken based on the judgment of the researcher to meet the objective of the study.

\section{Data Gathering instruments:-}

The study utilized questionnaires. The questionnaires were constructed by the researcher and validated by expert to judge its content. They were distributed to employees of the Divine Word Colleges. The questionnaires were consisted of two parts. First part is perception of employees of organizational politics. Second part is job satisfaction of employees.

\section{Data Gathering Procedures:-}

In the process of data gathering, the researcher sent letters to the Presidents of the three colleges requesting the Presidents to allow the researcher to flow his questionnaires in his college. The researcher personally met the Presidents and employees and requested them to answer the questionnaires.

The retrieval of questionnaires was arranged between the President's representative and the researcher with the help of employees and faculty of the three colleges. 


\section{Statistical Treatment of Data:-}

In consistent with the study as descriptive research, therefore descriptive statistics was used to measure frequency distribution and percentage and the weighted mean.

The weighted mean was used to assess the employees' perception of organizational politics and job satisfaction. To determine the relationships between employees' perception of organizational politics and job satisfaction, Pearson $\mathbf{r}$ was used. The following ranges of values with their descriptive interpretation were used:

\begin{tabular}{lll} 
Scale & Range of Weighted means & \multicolumn{1}{c}{ Descriptive interpretation } \\
5 & $4.21-5.00$ & Strongly Agree \\
4 & $3.41-4.20$ & Agree \\
3 & $2.61-3.40$ & Somewhat Agree \\
2 & $1.81-2.60$ & Disagree \\
1 & $1.00-1.80$ & Strongly Disagree
\end{tabular}

\section{Results:-}

Problem 1. What is the organizational politic of Divine Word Colleges' employees in Ilocos Region, Philippines? Problem 1a. Blaming Others

\begin{tabular}{|c|c|c|c|}
\hline \multicolumn{4}{|c|}{ Blaming Others } \\
\hline & & $\mathrm{X}$ & DR \\
\hline \multirow{2}{*}{\multicolumn{2}{|c|}{ 1. 1. Often time management does not take the responsibility when things go wrong. }} & 2.9 & SW \\
\hline & & 1 & A \\
\hline \multirow{2}{*}{\multicolumn{2}{|c|}{ 2. Instead of taking the blame, the management looks for scapegoats. }} & 2.9 & SW \\
\hline & & 2 & A \\
\hline \multirow{2}{*}{\multicolumn{2}{|c|}{$\begin{array}{l}\text { 3. It is also common among employees that they are not taking the responsibility when thing go wrong } \\
\text { but blaming the management. }\end{array}$}} & 3.0 & SW \\
\hline & & 2 & A \\
\hline \multirow{2}{*}{\multicolumn{2}{|c|}{ 4. It is more often than not that employee blaming each other when they fail to achieve their objectives }} & 2.9 & SW \\
\hline & & 7 & A \\
\hline \multirow{2}{*}{\multicolumn{2}{|c|}{ 5. Since I work here in this institution, I feel that I am always being blamed }} & 2.3 & DA \\
\hline & & 6 & \\
\hline \multirow{2}{*}{\multicolumn{2}{|c|}{$\begin{array}{l}\text { 6. There is a group of people in this institution who pretends to be correct always and blame other } \\
\text { people when they committed mistakes }\end{array}$}} & 3.3 & SW \\
\hline & & 1 & A \\
\hline \multirow{2}{*}{\multicolumn{2}{|c|}{ 7. Some employees are always blamed, while others are not blamed even if they are doing wrong }} & 3.2 & SW \\
\hline & & 9 & A \\
\hline \multirow{2}{*}{\multicolumn{2}{|c|}{ 8. People are hesitant to take the initiative because they will be blamed when they fail }} & 3.2 & SW \\
\hline & & 2 & A \\
\hline \multirow{2}{*}{\multicolumn{2}{|c|}{ 9. Creativity is hampered because employees are afraid of committing mistakes }} & 3.1 & SW \\
\hline & & 5 & $\mathrm{~A}$ \\
\hline \multirow{2}{*}{\multicolumn{2}{|c|}{ Overall }} & 3.0 & SW \\
\hline & & 2 & A \\
\hline \multicolumn{4}{|l|}{ Legend } \\
\hline $4.21-5.00$ & \multicolumn{3}{|l|}{ Strongly Agree } \\
\hline $3.41-4.20$ & \multicolumn{3}{|l|}{ Agree } \\
\hline $2.61-3.40$ & \multicolumn{3}{|l|}{ Somewhat Agree } \\
\hline $1.81-2.60$ & \multicolumn{3}{|l|}{ Disagree } \\
\hline $1.00-1.80$ & \multicolumn{3}{|l|}{ Strongly Disagree } \\
\hline
\end{tabular}

As it is shown on the table, the data reveals that as a whole, employees of Divine Word Colleges in Ilocos Region somewhat agree (3.02, SWA) on the existence of political behaviors in terms of blaming others. Employees somewhat agree that blaming others is existing in their school. Even when taking them singly, the employees somewhat agree that often time management does not take the responsibility when things go wrong (2.91), they look for scapegoat (2.92), and at the same time, employees do not take the responsibility but blaming the management (3.02) when things go wrong, and they blame each other when they fail to achieve the objectives ((2.97), but individually, he/she disagrees that he/she is being blamed (2.36). The rest of the questions have the same degree of 
acceptance on the existence of political behaviors such as a group of people pretends to be corrected always and blame others for their mistake (3.31) and some employees are always blamed and others are not blamed even if they are doing wrong (3.29), are hesitant to take initiative because of fear of being blamed (3.22), and are afraid of committing mistakes (3.15).

Problem 1b. Impression Management

\begin{tabular}{|c|c|c|}
\hline Impression management & $\mathrm{X}$ & DR \\
\hline 1. It is very common that some employees look for personal favor with their superior & $\begin{array}{l}3.0 \\
6\end{array}$ & $\begin{array}{l}\text { SW } \\
\text { A }\end{array}$ \\
\hline $\begin{array}{l}\text { 2. Some employees always present themselves to be competent and knowledgeable in front of their } \\
\text { supervisor }\end{array}$ & $\begin{array}{l}3.3 \\
9\end{array}$ & $\begin{array}{l}\text { SW } \\
\text { A }\end{array}$ \\
\hline 3. They praise their supervisor on their accomplishment & $\begin{array}{l}3.5 \\
5\end{array}$ & A \\
\hline 4. Compliment their immediate supervisor on his/her dress or appearance. & $\begin{array}{l}3.4 \\
8\end{array}$ & A \\
\hline Overall & $\begin{array}{l}3.3 \\
7\end{array}$ & $\begin{array}{l}\text { SW } \\
\text { A }\end{array}$ \\
\hline
\end{tabular}

Legend

4.21-5.00

$3.41-4.20$

2.61-3.40

1.81-2.60

$1.00-1.80$

\author{
Strongly Agree \\ Agree \\ Somewhat Agree \\ Disagree \\ Strongly Disagree
}

Based on the computed mean, it shows that as a whole, the employees somewhat agree (SWA) on the existence of impression management as indicated by its computed mean of 3.37 (SWA). The employees somewhat agree that some employees look for personal favor from their superiors (3.06), they present themselves to be competent and knowledgeable in front of their superiors (3.39), they praise their superior for their accomplishment (3.55) and complement their immediate superior on their dress or appearance (3.48).

\section{Problem 1c. Ingratiation}

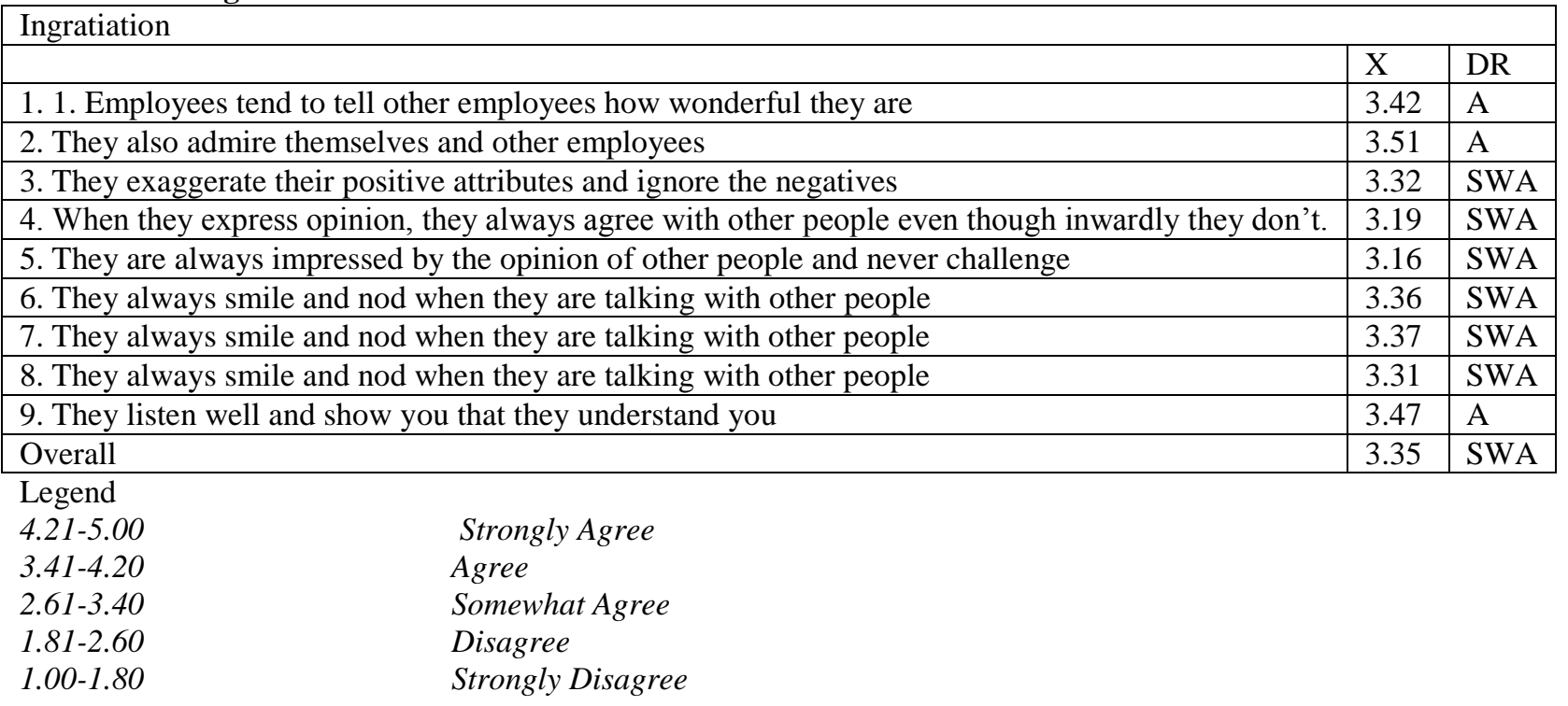

As it is gleaned from the data, it reveals that as a whole, employees somewhat agree on the presence of political behavior in terms of ingratiation. The employees somewhat agree that ingratiation is existing in their institution as indicated by its overall mean of 3.35 (SWA). Even when they are taken singly, the employees somewhat agree that there are employees who exaggerate their positive attribute and ignore their negative attributes (3.32), they always agree with other people even though inwardly they don't (3.19), they are always impressed by the opinion of others 
and never challenge it (3.16), and they are always smile and nod when they are talking with other people (3.3.6). They also agree that employees tend to tell other employees how wonderful they are (3.42), they admire themselves and other employees (3.51) and they listen well and show you that they understand you (3.47).

Problem 2: What is the job satisfaction of employees of Divine Word Colleges in Ilocos Region?

\begin{tabular}{|c|c|c|}
\hline \multicolumn{3}{|l|}{ Satisfaction } \\
\hline & $\mathrm{X}$ & DR \\
\hline 1. 1. I am generally satisfied with my current job. & 3.72 & A \\
\hline 2. In general, I love the work I do & 3.90 & A \\
\hline 3. All in all, I like the working environment of the school & 3.51 & A \\
\hline 4. I am excited to show up for work every day & 3.66 & A \\
\hline 5. I am satisfied because my administrators treat all employees the same. & 3.22 & SWA \\
\hline 6. I am happy because there is not much politics in our school & 3.22 & SWA \\
\hline 7. I am satisfied because all employees can work together to carry out common objectives & 3.28 & SWA \\
\hline 8. I am happy because my work and my accomplishment are recognized & 3.36 & SWA \\
\hline 9. My job is important to me & 4.16 & A \\
\hline 10. I am happy with the spirit of community in this school & 3.65 & A \\
\hline Overall & 3.57 & A \\
\hline
\end{tabular}

Legend

4.21-5.00

Strongly Agree

$3.41-4.20$

Agree

2.61-3.40

Somewhat Agree

$1.81-2.60$

Disagree

$1.00-1.80$

Strongly Disagree

As it is presented on the table, the data shows that as a whole, employees of Divine Word Colleges in Ilocos Region agree that they are satisfied with their job as indicated by its mean value of 3.57 which mean agree or satisfied. Even when seen individually, it shows that employees agree that they are satisfied with their current job (3.72), love their work (3.90), like the working environment (3.51), are excited to show up for daily work (3.66), happy with the spirit of community of the school and happy because their work and accomplishment are recognized. It also shows that the employees somewhat agree that the administrators treat employees the same (3.22), and they are happy and satisfied because there is not much politics (3.22) and employee are working together (3.28).

Problem 3: Is there a relationship between organizational politics and job satisfaction?

\begin{tabular}{|l|l|}
\hline Relationship between Organizational politics and job Satisfaction & $-0.3880^{*}$ \\
\hline Blaming Others & -0.1267 \\
\hline Impression Management & 0.0856 \\
\hline Ingratiation & -0.1430 \\
\hline As a whole & \\
\hline
\end{tabular}

*Significant at .05 level

Based on the correlation table, the data reveals that as a whole, there is no correlation between organizational politics and job satisfaction of employees. Taking them singly, impression management and ingratiation have no correlation with job satisfaction, but correlation exists between blaming others and job satisfaction. Thus, the hypothesis of the study is rejected which claims that there is a relationship between organizational politics and job satisfaction.

\section{Conclusion:-}

The study concludes that the Divine Word Colleges' employees somewhat agree to the existence of the organizational politics in terms of blaming others, impression management and ingratiation. Based on the findings, the study found that, as a whole, there is no correlation between organizational politics and job satisfaction of employees. Therefore, the hypothesis of the study is rejected. The study confirms the finding of other researcher such as Singh (2012) and Gull and Zaidi (2012) that organizational politics have a negative relationship with job 
satisfaction. However, taking it singly, organizational politics in terms of blaming others is correlated to the job satisfaction of employees.

\section{Recommendation:-}

Breaux, Munyon, Hochwarter, and Ferris, (2009) argued that when an organization staffed with dissatisfied employees, the organization will experience difficulty in achieving its goals. Based on their theory, the current study recommends that the management should design programs or activities that can minimize political behavior among employees and the management maintain professionalism in carrying out their duties and responsibilities.

\section{Bibliography:-}

1. Allen, R.W., Madison, D.L., Porter, L.W., Renwick, P.A., \& Mayes, B.T. (1979). Organizational Politics: Tactics and Characteristics of its Actors. SAGE Journals, Vol. 22, Issue 1, 1979.

2. Barcharach, S.B., \& Lawler, E.J. (1980). Power and Politics in Organizations. The Social Psychology of Conflict, Coalitions and Barganing". San Francisco: Jossey -Bass Publishers,

3. Bernstein, D. A., \& Nash, P. W. (2008). Essentials of psychology (4th ed.). Boston: Cengage Learning. Retrieved from http://books.google.com/books?id=4Do-bFrt9tUC.

4. Bozeman, D.P. \&Kacmar, K.M. (1997). A Cybernetic Model of Impression Management in Organization; a scale development based on the Jones and Pittman taxonomy. Organizational Research Methods, Vol. 2, Issue 2, 187-206.

5. Brandon, R., \&Seldman, M. (2004). Survival of the savvy: High-integrity political tactics for career and company success. New York: Free Press;

6. Breaux, D.M., Munyon, T.P., Hochwarter, W.A., \& Ferris, G.R. (2009). Politics as Moderator of the Accountability -Job Satisfaction Relationship: Evidence Across Three Studies. Journal of Management, Vol. 35, Issue, 2, 307-326.

7. Butt, M.R., Imran, A., Shah, F.T., \& Jabbar, A. (2013). Perception of Organizational Politics and Job Outcomes in a Public Sector Organization: The Moderating Role of Teamwork.Middle-East Journal of Scientific Research 18 (9): 1268-1276, 2013.

8. Delle, E. (2013). The Influence of Perception of Organizational Politics on Employee Job Involvement and Turnover Intentions: Empirical Evidence from Ghanaian Organizations. European Journal of Business and Management, Vol.5, No.9, 2013.

9. Drory, A. \&Vogoda-Gadot, E. (2010). Organizational Politics and Human Resources Management: A Typology and the Israeli Experience. Human Resource Management review, Vol. 20, 194-202.

10. Dubrin, A. J. (2001). Leadership. ( $3^{\text {rd }}$ ed) New York: Houghton Mifflin

11. Elkhalil, Y.A. 2017.Organizational Politics and Employee Behavior:AComparison Between the U.S. and Lebanon. A Doctoral Dissertation:Walden University.

12. Farrel, D., \& Peterson, J.C. (1982). Patterns of Political Behavior in Organizations. Academy of Management Review, Vol. 7, No. 3, 403-412.

13. Ferris, G. R., Frink, D. D., Bhawuk, D. P., Zhou, J., \& Gilmore, D. C. (1996). Reactions of diverse groups to politics in the workplace. Journal of Management, 22, 23-44.

14. Froman, L.A. (1962). People and Politics. Englewood Cliffs, N.J: Prentice-Hall.

15. Fullerton, M. (2017). Do You Remember the Microsoft Windows Game Minesweeper? AWARDS: Performance Solution. Retrieved from https://edwps.com/organizational-politics-mike-fullerton/

16. Gandz, J., \& Murray, V.V. (1980). The Experience of Workplace Politics. Academy of Management Journal, $23,237-251$.

17. Goltz, S.M. (2014). Considering Political Behavior in Organization. The Behavior Analyst Today, Vol. 4, No. 3.

18. Gull, S. \& Zaidi, A.A. (2012). Impact of Organizational Politics on Employees' Job Satisfaction in the Health Sector of Lahore Pakistan. Interdisciplinary Journal of Contemporary Research in Business, Vol. 4, No. 2.

19. Herzberg, F. (1968). One more time: How do you motivate employees? Harvard Business Review, pp. 52-62

20. Hochwarter, W.A., Kacmar, C., Perrewe, P.L. \& Johnson, D. (2003). Perceived Organizational Support as a Mediator of the Relationship between Politics Perceptions and Work Outcomes. Journal of Vocational Behavior, 63, 438-456.

21. Hochwarter, W. A., Witt, L. A., \&Kacmar, K. M. (2000). Perceptions of organizational politics as a moderator of the relationship between conscientiousness and job performance. Journal of Applied Psychology, 85, 472478. 
22. Hochwarter, W. A., Ferris, G. R., Laird, M. D., Treadway, D. C., \& Gallagher, V. C. (in press). Nonlinear politics perceptions-work outcomes relationships: A three-study, five-sample investigation. Journal of Management.

23. Hulin, C. L., \& Judge, T. A. (2003). Job Attitudes. In W. C. Borman, D. R. ligen, \& R. J.

24. Jones, E.E. (1964). Ingratiation: a social psychological analysis, in Century Psychology Series, Meredith Publishing Company: New York.

25. Kacmar, K. M., \& Baron, R. A. (1999). Organizational politics: The state of the field, links to related processes, and an agenda for future research. In K. M. Rowland \& G. R. Ferris (Eds.), Research in personnel and human resources management (Vol.10, pp. 1-39). Greenwich: JAI Press Inc.

26. Kacmar, K. L., Bozeman, D. P., Carlson, D. S., \& Anthony, W. P. (1999). An examination of the perceptions of organizational politics model: Replication and extension. Human Relations, 52, 383-416.

27. Kacmar, K. M., \& Ferris, G. R. (1989). Theoretical and methodological considerations in the age-job satisfaction relationship. Journal of Applied Psychology, 74, 201-207.

28. Kilduff, M., \& Day, D. (1994). Do chameleons get ahead? The effects of self-monitoring on managerial careers. Academy of Management Journal, 37, 1047-1060.

29. Klimoski (Eds.), Handbook of psychology: Industrial and organizational psychology. Hoboken, NJ: Wiley.

30. Locke, E.A. (1976). The nature and causes of job satisfaction. In M.D. Dunnette (Ed.), Handbook of industrial and organizational psychology. Chicago: Rand McNally.

31. Longenecker, C.O. (1989). Truth or consequences: Politics and performance appraisal. Business Horizons, 32, 76-82.

32. Luthans, F., Hodgetts, R.M., \&Rosenkrantz, S. (1988). Real Managers. Cambridge, MA: Ballinger.

33. Malik, M. E. (2009).Relationship between Age, Perceptions of Organizational Politics and Job Satisfaction. Journal of Behavioral Sciences Vol. 19 Number 1-2 2009.

34. Maslow, A. H. (1943). A theory of human motivation. Psychological Review, 50, 370-396.

35. Maslyn, J. M., \&Fedor, D. B. (1998). Perceptions of politics: Does measuring different loci matter? Journal of Applied Psychology, 84, 645-653.

36. Mintzberg, H. (1983). Power in and Around Organizations. Englewood Cliffs: Prentice-Hall.

37. Muhammad, A. H. (2007). Antecedents of organizational politic perceptions in Kuwait business organizations. Competitiveness Review, 17(14), 234.

38. Nye, L. G., \& Wit, L. A. (1993). Dimensionality and construct validity of the perceptions of politics scale (POPS). Educational and Psychological Measurement, 53, 821-829.

39. Omisore, B.O., \& Nweke, A.N. (2014). The Influence of Power and Politics in Organization. International Journal of Academic Research in Business and Social Sciences, Vol. 4, No.7, July 2014 Singh, K. (2012). Relationship between organizational politics, jobs satisfaction and organizational commitment at UiTIM Sarawak, Malaysia. Business Engineering and Industrial Application Colloquium (BEIAC), 2012, IEEE.

40. Sofi, S.A. (2013). Organizational Politics and Its Components: An Overview. International Monthly Refereed Journal of Research in Management \& Technology, Vol. 11, 2013.

41. Susman, L. et.al. (2002). Organizational Politics: tactics, Channels and Hierarchical Roles. Journal of Business ethics, 40, 313-329.

42. Tedeschi, J.T. \&Melburg, V. (1984). Impression Management and Influence in the Organization. In S.B. Bacharah, \& Lawler, E.J (Eds). Research in the Socilogy of organizations, Vol. 3, 31-59

43. Tomaževič, N., Seljak, J., \&Aristovnik, A. (2014). "Factors Influencing Employee Satisfaction in the Police Service: The Case of Slovenia". Personnel Review, Vol. 43, Issue 2, 209-227. doi:10.1108/pr-10-2012-0176.

44. Valle, M., \&Perrewe, P. L. (2000). Do politics perceptions relate to political behaviors? Tests of an implicit assumption and expanded model. Human Relations, 53, 359-386.

45. Vredenburgh, D. \& Shea Van-Fossen, R. (2010). Human Nature, Organizational Politics and Human Resources Development. Human Resource Development Review, 9 (1), 26-47.

46. Vigoda-Gadot, E. \&Drory, A. (2006). Handbook of Organizational Politics, Cheltenham: Edward Elgar

47. Nugent, Pam, M.S. (2013). Organizational Politics in Psychology Dictionary.org. Retrieved from https://psychologydictionary.org/organizational-politics/

48. Vigoda-Gadot, E. \& Talmud, I. (2010). Organizational Politics and Job Outcomes: The Moderating Effect of Trust and Social Support.Journal of Applied Social Psychology,2010,40, 11, pp. 2829-2861.

49. Vigoda-Gadot, E. (2000). Organizational Politics, Job Attitudes, and Work Outcomes: Exploration and Implications for the Public Sector. Journal of Vocational Behavior, 57, $326 \quad-347$ (2000) doi:10.1006/jvbe.1999.1742. 
50. Vigoda-Gadot, E. (n.d).Organizational Politics and Job Performance: The Moderating Effect of Social Capital. Retrieved from www.ResearchGate.com.

51. Virtual Learning Environment (VLE). (2018). Politics in Organization. Retrieved from http://vle.du.ac.in/mod/book/view.php?id=9726\&chapterid=15607.

52. Wayne, S.J., \& Ferris, G.R. (1990). Influence Tactics, Affect, and Exchange Quality in Supervisor Subordinate Interactions: a Laboratory Experiment and Field study. Journal of Applied Psychology, Vol. 75, 487-499.

53. WebFinance, Inc. (2012). Organizational Politics. Retrieved from http://www.businessdictionary.com/definition/organizational-politics.html.

54. Elkhalil, Y.A. 2017.Organizational Politics and Employee Behavior:AComparison Between the U.S. 